\title{
A Prophetic Pedagogical framework for Islamic schools
}

\author{
Muhammad Abdullah \\ University of South Australia Adelaide South Australia \\ Corresponding e-mail: muhammad.abdullah@unisa.edu.au
}

\begin{abstract}
During the last 35 years Islamic or Muslim schools have sprung up in Europe, North America and Australia. Reasons for the establishment of these schools generally pertain to Islamic faith and quality of education. In the main the desire of parents is for their children to both maintain their faith and be positive participants in and contributors to society. In the struggle for legitimacy in regards to both the Muslim and wider communities there is a tendency for schools to concentrate on academic results and the formalities of Islamic faith rather than a holistic quality education for all. The schools are struggling to achieve the goals for which they were established. Researchers in the field argue that there is a need for these schools to examine pedagogical issues rather than just the addition of Islamic subjects and curriculum Islamisation. This paper presents the findings of $\mathrm{PhD}$ research into the Hadith literature and suggests that a fertile synthesis of the pedagogical principles of the Islamic tradition, particularly prophetic principles, and the pedagogical principles of contemporary educational thought, is the first major step required for these goals to be achieved. Such a synthesis is consistent with the manifestation of Prophetic principles throughout the history of the Muslim world and would give an explicit Islamic pedagogical framework for teachers, many of whom have also come from vastly differing education systems. Such a framework applied across all subjects allows students the opportunity to confidently experience an integrated approach to knowledge consistent with their Islam.
\end{abstract}

\section{INTRODUCTION}

Muslims tend to look to the Prophet Muhammad, as the model to which a person should aspire, in order to bring themselves closer to the pleasure of God. Often. An individual may display very little of that model in their own life, but still accepts the supremacy and infallibility of the model. As a result, founders of new 'Islamic' ideas and movements will attempt to legitimise their validity by demonstrating a connection, no matter how tenuous, to the practises and/or sayings of the Prophet. If the connection to the Prophetic model is not established, or is extremely tenuous, there remains the apprehension that the idea or movement could eventually face rejection by some or all members of the community.

However, the rationale for this study was not simply to seek validation from the Prophetic model, but rather to utilise the model in the establishment of best practise in Islamic schools whereby the objectives of parents and community in founding these schools may be realised. There are multiple reasons why a pedagogy that is in harmony with a Prophetic model and aligned with good pedagogical practice would be beneficial for an Islamic school. Firstly, from an Islamic worldview the emulation of the attributes and noble character of the Prophet is beneficial for the individual, in this case the educator. Secondly, the Prophet is established by Qur'an as a teacher, "It is He Who sent to the unlettered (folk) a messenger from among them to recite to them His signs, and to purify them (yuzakkiihim), and teach them (yu'allim) the Book and wisdom, though indeed before that, they had been in manifest error," and "For this we have sent a messenger to you from amongst you reciting to you Our signs, purifying you, teaching you the Book and wisdom and teaching you what you previously did not know." Given the assertion of the message's importance and the need to communicate it to an often indifferent, and on occasion's hostile audience, his pedagogy needed to be an effective pedagogy. Effective pedagogy in that it needed to be responsive to the needs of the individual in their own time and context. For Islamic schools this pedagogy would also be one that enables the conveyance of the Prophetic worldview, which is as such the exemplification of the Islamic worldview and character; "Indeed you are on an exalted standard of character" and "For you, in the messenger of Allah [God] is an excellent example." The Prophet's wife A'isha when asked about his character replied 'have you not read the Qur'an'? I said, 'yes' she then said, 'His character was the Qur'an (the embodiment of the Qur'an).. Thirdly, and maybe most importantly, both in Qur'an and hadith there is encouragement to strive for perfection in all actions. "(Those) who expend in prosperity and adversity, and restrain their rage, and pardon their fellow-men; and God loves those who are virtuous (strive for excellence)", and "God loves, that when a person does an action, they perfect it" and "The believer perfects his actions". 


\section{RECORD OF THE LIFE OF THE PROPHET}

However, the Qur'an does not provide a complete description of the Prophet's life, actions, words and character. Hence, after the death of the Prophet the record of these was regarded as extremely important for the growing community. This record became known as the Sunnah and Kamali notes that the scholars ('ulama') are unanimous that the Sunnah is a source of Shari'ah. The Sunnah is divided into three types: verbal (qawli), actual (fi'li) and those tacitly approved by his silence (taqriri). A further division of the Sunnah is into those which are used as legal sources for shari'ah and those which are non-legal such as matters peculiar to the person of the Prophet.

The writing and collection of Sunnah commenced in the time of the Prophet Muhammad with his companion, otherwise known as Sahabah. These earlier collections of hadith comprise the greater part of the later compilations. Documentation of the Sunnah was proposed in the time of the second Caliph Umar b. Al-Khattab (d. $23 \mathrm{H})$, but was not commenced to avoid distraction from Qur'an. However, compilation did commence in the time of the Caliph Umar b. Abdul-Aziz (d. $101 \mathrm{H}$ ) and continued through to the fourth century. With the passage of time, the compilations of renowned scholars, Bukhari and Muslim, have come to the fore along with the compilations of Tirmidhi, Abu Daud, Al-Nasai and Ibn Majah, and together, these make up the sihah sittah (six sound collections of hadith). Other famous compilations include the Muwatta of Malik bin Anas and the Musnad of Ahmad bin Hanbal.

By the third century hijri there was general agreement amongst Sunni scholars as to the basic principles for the classification of hadith authenticity. There are two major components to hadith authenticity: sanad (chain of narrators) and matn (text)- each had its own criteria, and particularly in the case of sanad, spawned new areas of scholarly research and specialisation. Second, third and fourth century hadith compilers often sifted through hundreds of thousands of hadith to produce compilations of just several thousand hadith. These hadith were classified under four broad categories; Authentic, Acceptable, Weak and Fabricated, with a number of sub-categories for each. Same text hadith reported with a different sanad were regarded as separate hadith. On elimination of fabricated hadith and duplication due to sanad difference and repetition between compilations, the total body of hadith is much smaller than the hundreds of thousands mentioned throughout the literature. Nevertheless, the number of hadith is in the tens of thousands. Numerous hadith have been included in compilations about the appearance, attributes and daily practices of the Prophet including the famous Shamaail Muhammadiyah by Al- Tirmidhi and Wasaa'il AlWasool ilaa Shamaa'il Al-Rasool by Al-Nabahani, and of course, in various biographies of the Prophet much of which is of a non-legally binding nature.

\section{PROPHETIC EXAMPLE}

Although much of this material is of a non-legally binding nature it still plays a significant role in Islam as an expression of love and a path to the inculcation of the love of the Prophet. This is particularly apparent on examination of the lives of the Prophet's companions, who out of their love for the Prophet adopted many of these matters peculiar to the person of the Prophet as their personal habits, "It was told to me by Mu'awiyah bin Qurrah from his father (May God be pleased with him) that he said that, "I came to the Messenger of God (May peace and blessings be upon him) when he was in the camp of Muzainah to take oath of allegiance and he had is buttons open and so I put my hand in the large inside pocket of his robe and felt the ring" Urwah said, "I never saw Mu'awiyah or his son after that in winter or summer except that they had their buttons undone". This is relevant when considering the object of Prophetic love as pointed out by Yusuf Nabhaani referring to the verse "Say, If you love Allah then follow me and Allah will love you" he then notes, "following his example, to whatever extent Allah the exalted gives him the ability, in his generosity, kindness, humility, abstinence, worship and other actions from his noble character and virtuous qualities is deserving of the love of Allah in which is the bliss of both worlds".

Al-Hakim Al-Tirmidhi, Abu Na'eem and Ibn Asaakir offer further support for this opinion with a report of an interpretation by $\mathrm{Abu}$ Darda that, "follow me' means: in piety, righteousness, humility, and humbleness". The concept that the Prophet is an example to be emulated in all matters is also supported by the interpretation of other verses, for instance, "Verily there is a good example in the Messenger of God for whoever hopes for (the encounter with) God and the Last Day, and remembers God often". Al-Qurtabi explains that it is an example you follow as a model in all actions and conditions. Relevant also is the narration by Ibn Umar that the messenger of Allah said, "The Believer does not complete his faith until his desires follow that which I have brought". The majority of scholars understand that 'following' in this hadith refers to matters of a legal nature, both compulsory and recommended. Others hold that by trying to emulate the Prophet, even in matters regarded as peculiar to him, one nurtures a love for the Prophet, potentially leading to a more complete adoption and application of religion, both exoterically and esoterically. "The believers with the most complete faith are those with the best of character and gentlest with their family". The explicit statements, actions and tacit approvals of the Prophet, as a teacher and a model, mean that each hadith from the Sunnah can be assumed as a teaching moment, and hence a manifestation of the Prophetic pedagogy, for example: Abu Zhar narrates that once the Holy Prophet came out of his house. It was autumn and the leaves were falling off the trees. He 
caught hold of a branch of a tree and its leaves began to drop in large number.

At this he remarked, "O, Abu Zhar! When a Muslim offers his salaat (daily prayers) to please Allah, his sins are shed away from him just as these leaves are falling off this tree".

\section{A PROPHETIC PEDAGOGICAL FRAMEWORK}

"Although there is no explicit Prophetic pedagogy or pedagogical Framework that is mandated by Shariah pedagogical principles can be identified implicitly from the hadith which may then be used to construct a pedagogical framework. The resultant framework as such cannot be described as 'the' Prophetic pedagogical framework but ' $a$ ' Prophetic pedagogical framework. The existence of Prophetic pedagogical principles and a pedagogical framework is important as it gives a dynamic platform for collegial discussion and planning in Islamic schools. In addition, a framework gives an opportunity for reflective teacher practice both for personal development and as measurement against accepted professional standards. The challenge was however, to identify a sound method of extracting and constructing a Prophetic pedagogical framework from the large body of Hadith. Each individual hadith considered as data, as mentioned above may be viewed as teaching moments and hence the task became the identification of these moments and subsequently through an inductive process ascertain general principles from which a pedagogical framework may be constructed. Therefore, it was decided to initially use an inductive process followed by a deductive process culminating in the attempt to create a fertile synthesis between the Prophetic Pedagogical Framework and the various pedagogical frameworks found in different Australian States. The inductive process used for coding was Glaserian Grounded Theory and an abridged version of Sahih Muslim was used as data.

After one hundred and seventy- two hadith were coded, there were one hundred and seventeen codes from which thirty - two categories emerged. These categories reduced to seven core categories; Building Relationships, Relevance, Deep knowledge and Understanding, Differentiation, Engagement, Authenticity of Knowledge and Language Precision. An example of this process in relation to category, "Respect for others" from core category Building Relationships is included in table 1. Once the core categories had been established, the hadith literature was examined further, to identify exemplars of each of the categories within the core categories. On construction of the Prophetical framework, the seven core categories were called Elements. The subcategories, were included with the elements, as descriptors of each element. The further hadiths identified were included as exemplars of features of the core categories. Included in table 2 below is a hadith that exemplifies features of sub categories of the building relationships core category.

Memorisation was added to the Prophetic Pedagogical Framework, despite not being identified in coding. This was done given its prevalence as a pedagogical principle throughout Islamic history. Memorisation traditionally was not just rote learning but rather intended for later deep understanding and deep knowledge.

\section{CONCLUSION}

For Islamic schools in Australia, it is contended that a synthesis between Productive Pedagogies and Prophetic pedagogy allows the achievement of the intended aims and objectives of Islamic schooling. The Queensland School Reform Longitudinal Study (QSRLS) is one of largest classroom based research projects ever undertaken in Australia. The study was commissioned by Education Queensland (EQ), and commenced in 1997 with the submission of the final report in 2001.

The researchers made detailed observations and statistical analyses of 975 classroom lessons offered in 24 Education Queensland schools over three years. The QSRLS observational data led to the four dimensions of the Productive Pedagogies framework which has been taken up widely in Australia and internationally as both a research tool and a metalanguage for critical teacher reflection. Productive Pedagogies was adopted by Education Queensland in 2001. Another similar framework based on the QSRLS data is The Quality Teaching Model, which was adopted by the NSW Department of Education and Training in 2006. An example of a possible fertile synthesis between the Prophetic Pedagogical and the Productive Pedagogies Frameworks is included at table $3 \mathrm{a}$ and $3 \mathrm{~b}$.

The implementation of such a synthesis in Islamic schools will assist in facilitating renewal and the establishment of quality teaching practices across all subject areas including Islamic studies aiming to improve learning outcomes for all student 


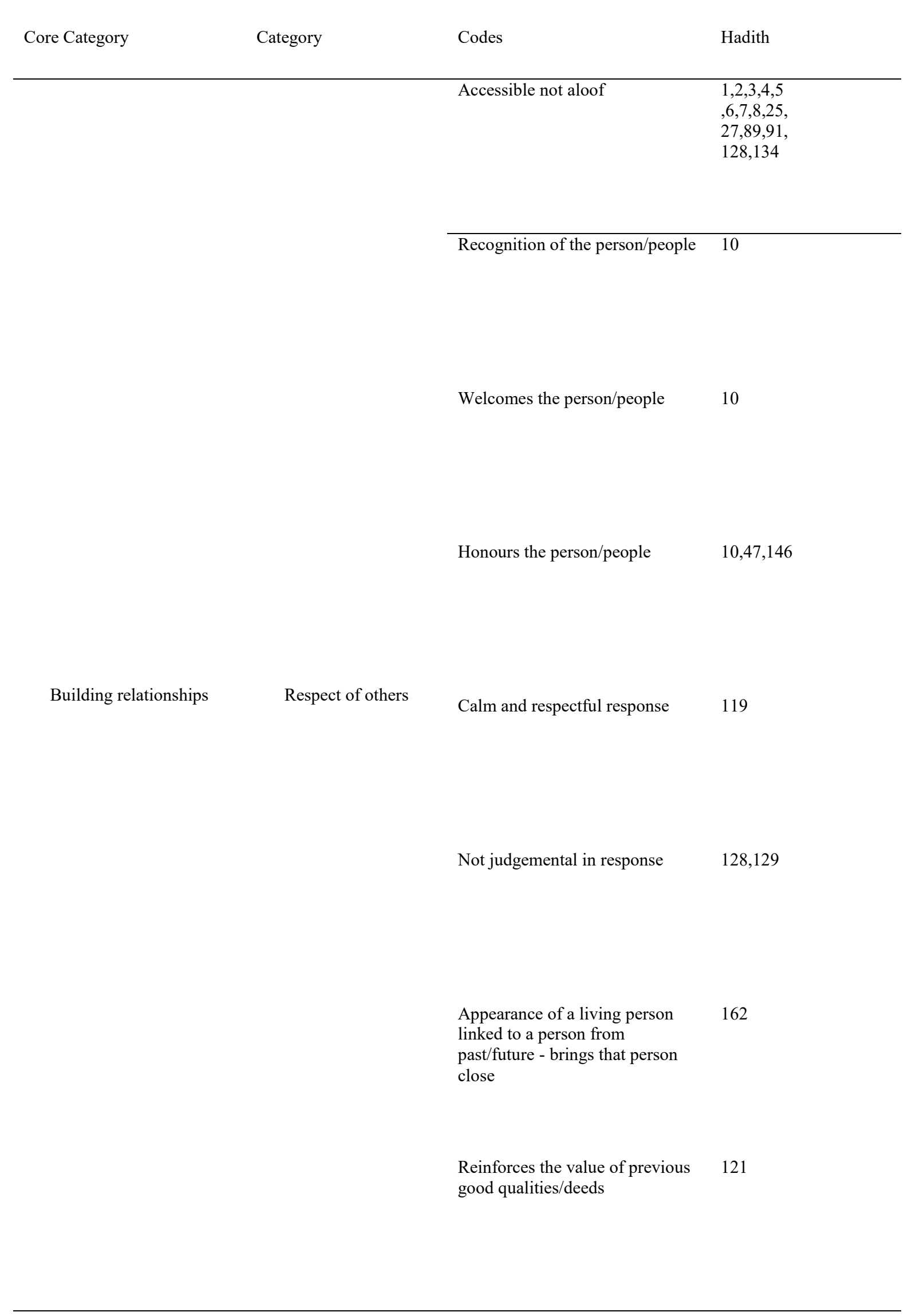


Table 2 Prophetic Pedagogical Framework

Building
Relationships

\begin{tabular}{ll}
\hline Feature & Hadith \\
All classroom & 1. Anas bin Maalik Radiyallahu \\
members feel & 'Anhu says: "I remained in the \\
comfortable to & service (of Rasulullah Sallallahu \\
take risks & 'Alayhi Wasallam for ten years. He \\
because there & never once told me 'Oof'. When I \\
are no put & did something, he never asked me, \\
downs & why did you do so? When I did not \\
& do a certain task, he never asked me \\
& why I did not do it. (Shamaail \\
& Tirmidhi- 346 \{Ar.\} 328 \{ng.\}) \\
& 2. From a narration of Hasan bin \\
& 'Ali Radiyallahu 'Anhu,"...the \\
& whole creation was equal before him \\
& as far as rights were concerned. His \\
& gatherings were the gatherings of \\
knowledge, modesty, patience and & honesty. (i.e. These four things were \\
attained there or are a description of & his gatherings). Voices were not \\
raised therein, nor was anyone \\
degraded or disgraced. If anyone \\
committed a fault, it was not made \\
known publicly...(Shamaail \\
Tirmidhi Hadith 337 AAr.\} \\
319\{Eng.\}) \\
\end{tabular}

Table 3a

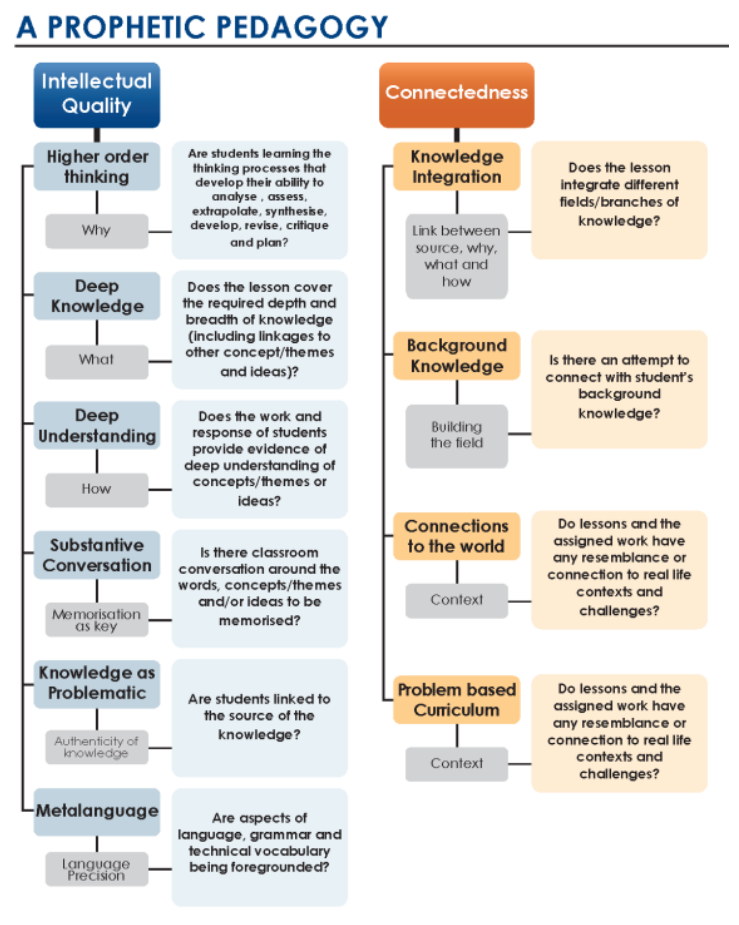

Table $3 b$

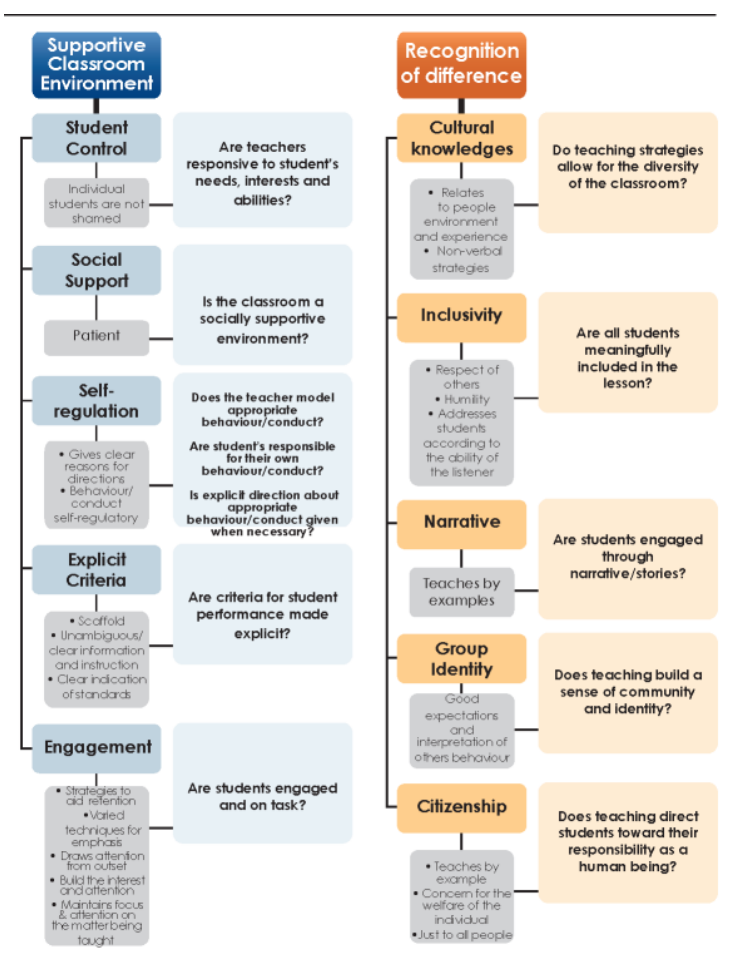




\section{REFERENCES}

Clyne Donohoue I. (2000). The Struggle of Muslims to educate their children in Australia. PhD Theses. University of Melbourne Retrieved May 182009 from University of Melbourne Library

Qur'an 62:2 on Abu Ghuddah, A. (1996). Al-Rasool AlMuallim. Beirut: Maktabatul Matbuaat Al Islamiyyah.

Kandhalawi M. Y. (1999). Hayaatus Sahabah. Beirut: Dar ibn Hazm, No 2406.

Kamali, M. H. (2008). Shari'ah law: an Introduction. Oxford: Oneworld Publications.

Kamali (2008). the discussion in chapter is instructive in the clarification of the role and place of Shari'ah in Islam.

Kamali, M. H. (2005) A textbook of Hadith Studies. Markfield: The Islamic Foundation.

Kamali, M. H. (2005) A textbook of Hadith Studies. Markfield: The Islamic Foundation.

Kamali, M. H. (2005) A textbook of Hadith Studies. Markfield: The Islamic Foundation.

Ali, S. B. (2003). Scholars of Hadith. Skokie: IQRA' International Educational Foundation.

Nadwi, S. A. A. (2005). Hadith Status and Role: An Introduction to the Prophet's Tradition. Leicester: UK Islamic Academy.

Ali, S. B. (2003). Scholars of Hadith. Skokie: IQRA' International Educational Foundation.

Al-Nabahani Y. I. (2004). Wasaail al-Wusuul ila Shamaail al-Rasuul

Tafsir Al-durrul-manthur fi tafsiirul-ma'thur Al-Suyuti (911) http://www.altafsir.com/Quran_Search_Eng.asp accessed 11july 2017

Al-Qurtabi (d. 671 A.H.) Al-Jaami' Li-Ahkaam Al-Qur'an accessed in www.altafsir.com

Al Tirmidhi; Al-Jami' As-Sahih in, An-Nawawi, Imam (2003). Riyadhus Salihiin. Cairo: Daarul Hadith: hadith.

Kandhalawi, M. Z. (1997). Faza'il-E-A'mal. Karachi: Zam Zam Publishers.

Glaser, B. G. (1978). Theoretical Sensitivity: Advances in the methodology of Grounded Theory. Mill Valley, Sociology Press.

Shamsuddin, A. (1998). Abridge Sahih Muslim. Beirut, Dar al-Kotob al-Ilmiyah.

Boyle, H. N. (2002, March 6-9). The growth of Qur'anic Schooling and the Marginalization of Islamic pedagogy. Paper presented at the Annual meeting of the Comparative and International Education Society. Retrieved April, 27, 2007 from Proquest database

Education Queensland (2001). Productive Pedagogies. Retrieved September, 23, 2009 from http://education.qld.gov.au/curriculum/learning/teac hing/technology/pedagogy/ index.html

Hayes, D., Mills, M., Christie, P., \& Lingard, B. (2006). Teachers and Schooling Making a Difference. Crows Nest: Allen and Unwin

Mills, M., Goos, M., at.al. (2009). Productive Pedagogies: A Redefined Methodology for Analysing Quality Teacher Practice. The Australian Educational Researcher, Vol. 36(3), pp. 67-87. 